\title{
DIFFERENCES IN SOCIAL AND MACHIAVELLIAN INTELLIGENCE BETWEEN THE MANAGEMENT STUDENTS FROM THE CZECH AND SLOVAK REPUBLIC
}

\author{
Miroslav Frankovský, Zuzana Birknerová, University of Prešov in Prešov, \\ miroslav.frankovsky@unipo.sk, zuzana.birknerova@unipo.sk
}

\begin{abstract}
Identifying and specifying social and Machiavellian intelligence is related to the broader discussion about the existence of several kinds of intelligence. When characterizing these two particular types it is inevitable to take a broader social context defining them into account. In the report we present the results of comparisons of assessing the selected attributes of social and Machiavellian intelligence by the management students from Czech Republic and Slovakia by means of the TSIS methodology, Mach IV and EMESI - an own methodology for detecting social intelligence. The presented comparisons are based on the influence of the macrosocial and microsocial environments on perception of the studied types of intelligence. This comparative analysis is connected also to the theoretical and methodological verification of the original methodology for measuring social intelligence - EMESI.
\end{abstract}

JEL Classification Numbers: M12, M14, DOI: 10.12955/cbup.2013.26

Key words: social intelligence, Machiavellian intelligence, management students, intercultural analysis

\section{Introduction}

Identifying and specifying social and Machiavellian intelligence is related to the broader discussion about the existence of several kinds of intelligence (Sternberg, 1986, Gardner, 1993, Goleman, 2006, Bar-On, 2006, Albrecht, 2006 and others).

The study presented in this report focuses on the macrosocial interconnections of studying social and Machiavellian intelligence represented by the context of the country and the residence and is analyzed on the sample of management students from Slovakia and Czech Republic. We realize there are certain obstacles within the given intercultural investigation on the basis of the respondents from Czech and Slovak Republic, therefore we regard it as the first step towards the analyses of intercultural influences on social and Machiavellian intelligence.

\section{Social intelligence}

A discussion, which was created as part of conceptualization and the subsequent operationalization of social intelligence, brings the authors' attention to at least four areas of issues (Frankovský et al., 2012): 
1. Differentiation and specification of defining social intelligence in relation to similar, related areas of knowledge, primarily in connection to intelligence and emotional intelligence.

2. Ethical dimension of implication of social intelligence in practical life.

3. Defining the structural elements of the social intelligence construct.

4. Personality and psychometric approach to studying and detecting social intelligence.

The first two areas are connected primarily to the theoretical definition of social intelligence, the latter two are related mainly to the quantification of social intelligence or the possibilities of its detection and measuring. These issue areas may be complemented with one more area related to the prediction of human behavior in certain concrete situations which represents an application potential of social intelligence and thus also its use in the social practice in the selection of people, their preparation, analysis of human failures, etc.

The issue of the purpose of the development of a methodology for measuring social intelligence oriented personality-wise or in the psychometric direction resonated also in our efforts when proposing and verifying the measuring tool of this construct.

The concrete result and outcome of these efforts was a proposal and an analysis of the basic parameters of the SIPS or SIPS(r) methodology (Solving Interpersonal Situations and its revised version; Frankovský, 2010; Frankovský \& Birknerová, 2011) which represents the personality approach, while the EMESI methodology (Frankovský \& Birknerová, 2012) represents the psychometric approach to studying social intelligence.

On the basis of developing and verifying the EMESI methodology, several studies had been carried out. Besides the usual research sample represented by the university students the studies included also the samples from the economically active population represented primarily by managers (Birknerová \& Lelková, 2012).

\section{Machiavellian intelligence}

Byrne, Whiten (1988, Calvin 2000) describe Machiavellian intelligence as an ability to successfully and purposefully manipulate with the participants in a social interaction with an aim to reach their own goals motivated primarily by selfishness and power.

They base these descriptions on the research in social behavior of primates in their natural environments, which uncovered some very complex structures in their social hierarchy and complex, strictly defined, power-oriented, competitive, and cooperative interrelations. Among these there is, for example, a discovery of the ability to lie systematically and purposefully to the members of an own social group.

Machiavellism involving manipulation with an aim to reach personal goals, increase and maintain the power over others is based on an unethical conduct - intentional lying, blandishments, and lack of moral judgment (Grams \& Rogers, 1989). Machiavellists dislike cooperation with others, they lack empathy and strictly follow their goals (Andrew et al., 2008).

A Machiavellistic personality has four main characteristics - relative lack of emotion in interpersonal relations, lack of interest in conventional morale, personality pathology, and little ideology commitment (Christie, 1970). 
Machiavellists are convincing liars and it is difficult to distinguish between their lies and truths. Their lies are aimed at manipulation and self-presentation which is connected to their narcissism (Vernon, Vilani, Vickers \& Harris, 2008).

\section{Research}

The research was conducted on 469 university students of management. There were 245 respondents from Slovakia (22\% of them were men, $78 \%$ women, the average age was 22.3 years with standard deviation of 2.905) and 206 university students from the Czech Republic (24\% men, $76 \%$ women, the average age of 25.3, and standard deviation of 6.709). In the Slovak sample of students, $58 \%$ came from the city and $42 \%$ from the countryside, and the Czech sample contained $60 \%$ respondents from the city and $40 \%$ from the countryside.

In this research, social intelligence was detected by means of the EMESI (Frankovský, Birknerová, 2012) and the TSIS (Silvera, Martinussen \& Dahl, 2001) methodologies.

EMESI methodology (Frankovský \& Birknerová, 2012) for measuring social intelligence as a performance characteristics is inspired by the PESI methodology, which was developed by authors Kaukiainen, Björkqvist, Osterman, Lagerspetz, and Forsblom (1999).

The original methodology was created for their peers or their teachers and was aimed to detect the degree of perceiving social intelligence as a performance characteristic. It contains 10 items and its inner consistency (Cronbach's alpha) is 0.90 .

During its development, EMESI had to undergo several modifications. On the basis of the results of an analysis of saturation of the extracted factors by the individual items of the methodology but also regarding the results of the reliability analysis (Cronbach's alpha calculation was used), the number of items in the methodology was gradually reduced to 21 and these were assessed on a 5-point scale of the Likert type ( 0 - never, 4 - very frequently). Three factors, which were extracted by means of a factor analysis, were content-wise specified as follows:

1. Empathy: Individuals scoring higher in this factor are able to identify the intentions, feelings and weaknesses of other people. They can adapt to new people, guess and also fulfill their wishes (Cronbach's alpha - 0.781);

2. Manipulation: People with higher scores in this factor are able to persuade others to do what they need from them. They know how to use them for their own benefit and persuade them to stand at their side. They use lies for their advantage (Cronbach's alpha - 0.859);

3. Social irritability: Persons characterized by higher scores in this factor become nervous in a contact with other people. Feeling of others make them uncomfortable, adapting to others represents a problem for them. Weaknesses and wishes of others distract them. They become nervous of the people who are willing to do anything for them (Cronbach's alpha -0.679).

TSIS methodology - Tromso Social Intelligence Scale (Silvera, Martinussen, Dahl, 2001) contains 21 self-evaluation items to which the respondents answer on a 7-point scale of the degree of agreement (1 - describes me poorly, 7 - describes me very well). The questionnaire is divided into three subscales and enables specification of 3 factors:

- $\mathrm{SP}$ - social information processing (e.g. I easily understand social situations), 
- $\mathrm{SS}$ - social skills (e.g. I am successful in establishing new relationships),

- SA - social awareness, social perception - (e.g. I am often surprised by how others react to my actions).

Reliability of these factors is stated as follows: SP -0.79 , SS -0.85 and SA -0.72 (Silvera, Martinussen \& Dahl, 2001). Machiavellian intelligence was detected by means of the Mach IV methodology (Hunter, Boster \& Gerbing, 1982).

Mach IV scale contains 20 statements which are related to a respondent's personal opinion on relationships, situations, strategies and values among people, responding to which is carried out by means of a scale from " 1 - completely disagree" to " 5 - completely agree".

The methodology enables identification of four components of the central dimensions of Machiavellism: blandishments, deceit-lie, immorality and cynicism (Hunter, Boster \& Gerbing, 1982).

\section{Results}

Macrosocial environment represented, for example, by culture, political system, social control, closeness, openness of social ties and many other factors may influence the psychological attributes such as social and Machiavellian intelligence. At the level of macrosocial environment, this phenomenon was operationalized at the level of country (Czech and Slovak Republic) and residence (city and countryside).

The gained results were analyzed by using the two-factor analysis of variance - ANOVA. Country and residence were included in the presented analysis as the independent factor, the dependent variables were represented by the indicators of social and Machiavellian intelligence.

From the viewpoint of analysis of the whole model, only the factor of country proved to be statistically significant. The factor of residence and the interaction of the factors of country and residence were not found to be statistically significant (Table 1).

An analysis of the data confirmed the existence of the statistically significant differences in the context of the factor of country in the comparison of the responses of the management students from Slovakia and Czech Republic in relation to the indicators of social intelligence (social information processing, empathy, manipulation). The boundary of statistical significance was approached by the differences in the assessment of social skills as an indicator of social intelligence and the Machiavellian intelligence indicator of deceit-lie (Table 2).

Social information processing and social skills were rendered by the respondents from Slovakia as more representative. These respondents evaluated the social intelligence factor of empathy more positively as well. The Czech respondents clearly rejected manipulation, which was also done by the management students from Slovakia but with a difference in the degree of rejection of this social intelligence factor.

In the context of the factor of residence, several differences were detected in the responses between the respondents from the city and those from the countryside, which approached the statistical significance only in relation to the indicator of Machiavellian intelligence (deceit-lie; Table 2). Although both groups of respondents mildly agreed with this indicator of Machiavellian intelligence, a higher degree of agreement was demonstrated by the respondents from Slovakia. 


Table 1: Analysis of the factors of country and residence and the interaction of these fact
\begin{tabular}{|l|l|l|}
\hline Effect & F & Sig. \\
\hline Country & 2.152 & .020 \\
\hline Residence & .569 & .839 \\
\hline Country*Residence & 1.099 & .362 \\
\hline
\end{tabular}

Source: Authors

Despite the fact that no statistically significant influence of the interaction between the factors of country and residence for evaluation of the social and Machiavellian intelligence indicators were detected, we present a graphical illustration of the selected results of this interaction analysis.

Table 2: Statistically significant differences in evaluating the indicators of social and Machiavellian intelligence from the viewpoint of country and residence

\begin{tabular}{|l|l|c|c|c|c|}
\hline \multirow{5}{*}{ Source } & Dependent Variable & $\begin{array}{c}\text { Slovakia } \\
\text { mean }\end{array}$ & $\begin{array}{c}\text { Czech Republic } \\
\text { Mean }\end{array}$ & F & Sig. \\
\hline Country & $\begin{array}{l}\text { Social information } \\
\text { processing }\end{array}$ & 5.124 & 4.829 & 6.895 & .009 \\
\cline { 2 - 6 } & Social skills & 4.700 & 4.429 & 2.909 & .089 \\
\cline { 2 - 6 } & Empathy & 2.708 & 2.497 & 10.745 & .001 \\
\cline { 2 - 6 } & Manipulation & 1.671 & 1.467 & 7.528 & .006 \\
\cline { 2 - 6 } & Deceit-lie & 3.717 & 3.483 & 2.743 & .099 \\
\hline Residence & Deceit-lie & City & Countryside & & .091 \\
\hline
\end{tabular}

Source: Authors

When evaluating the social intelligence factor of social skills, the Czech respondents from the countryside assessed this factor higher than those from the city, which differs from the results of the Slovak respondents. In their case, the respondents from the city evaluated social skills higher than those from the countryside (Figure 1).

When assessing the social intelligence factor of social irritability, this factor was evaluated by the Czech respondents from the city lower than by those from the countryside, which is different from the results of the Slovak respondents, in whose case this factor had a lower evaluation by the respondents from the countryside than by those from the city (Figure 2).

When evaluating the Machiavellian intelligence factor of blandishments, the Czech respondents from the city assessed this factor higher than those from the countryside, which differs from the results of the Slovak respondents. In their case, the respondents from the countryside evaluated this factor higher than those from the city (Figure 3). 
CBU INTERNATIONAL CONFERENCE ON INTEGRATION AND INNOVATION IN SCIENCE AND EdUCATION

Figure 1: Evaluation of social skills (TSIS) from the viewpoint of the factors of country and residence

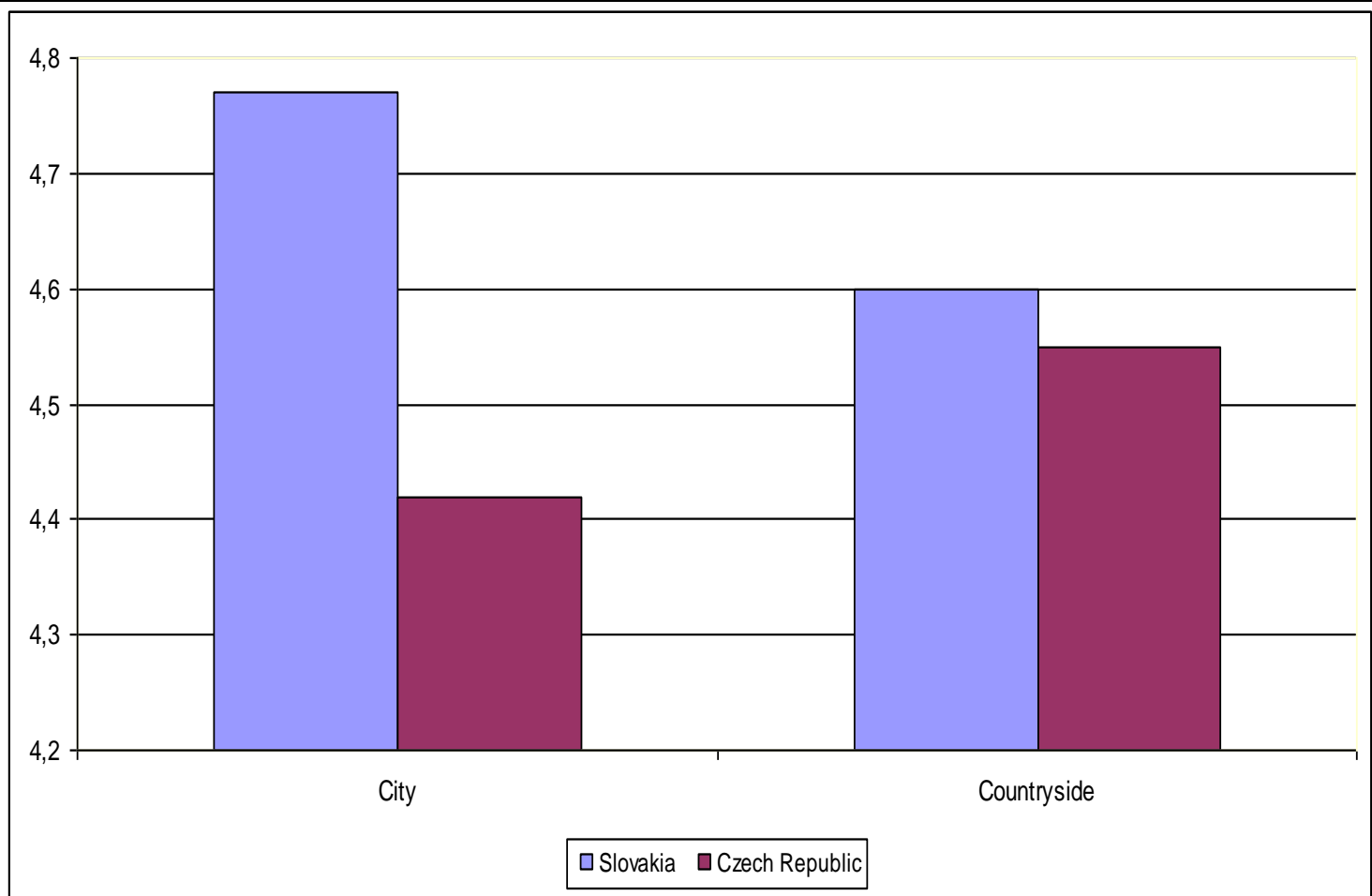

Source: Authors

Figure 2: Evaluation of social irritability (EMESI) from the viewpoint of the factors of country and residence

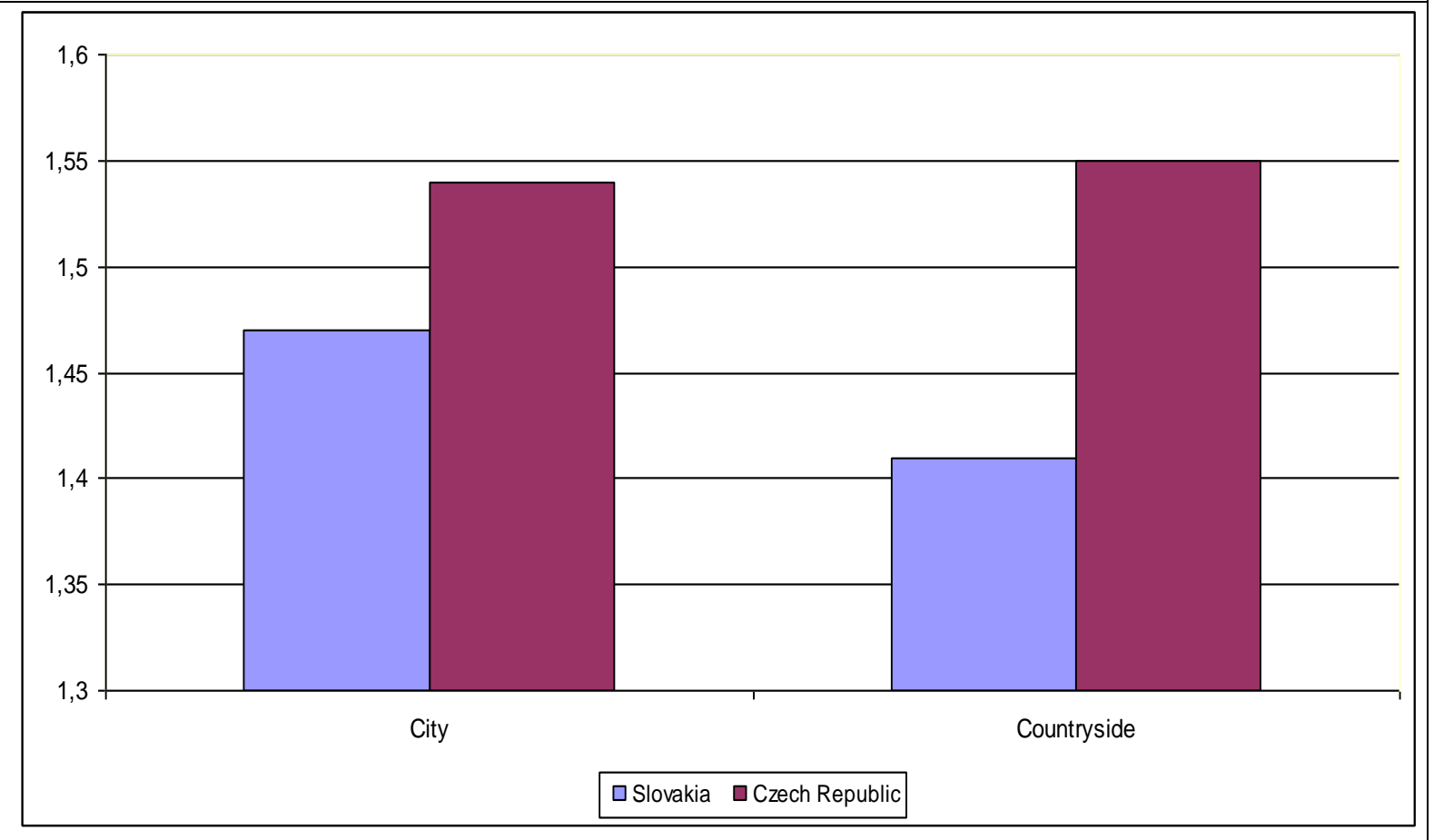

Source: Authors 
Figure 3: Evaluation of the factor of blandishments (MACH IV.) from the viewpoint of the factors of country and residence

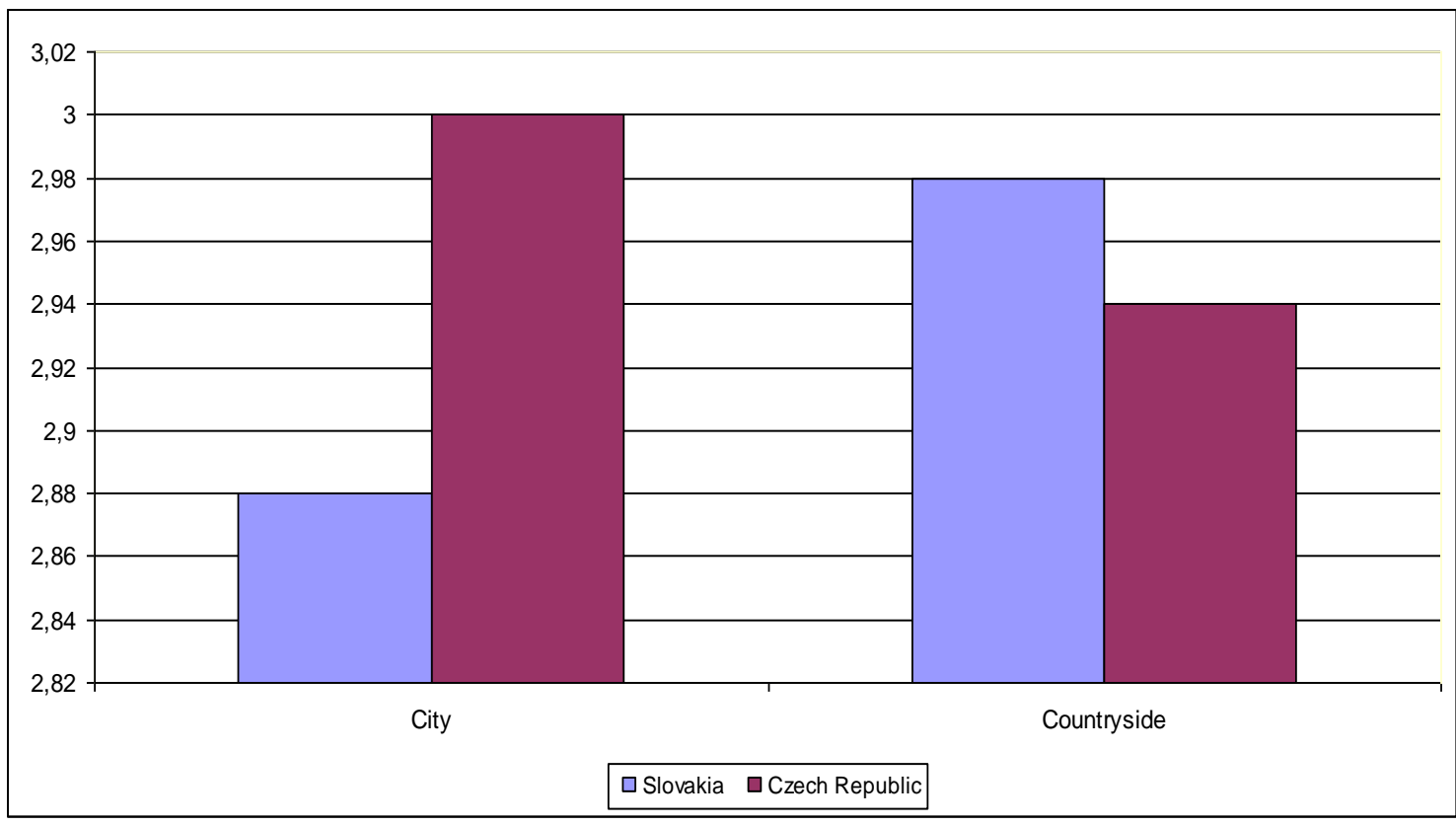

Source: Authors

\section{Conclusion}

The presented results and knowledge confirm the meaningfulness of researching the macrosocial contexts of social and Machiavellian intelligence. It is evident that the studied macrosocial phenomena do not affect the individual structural elements of social and Machiavellian intelligence equally. In the context of this research, the influence of the country proved to be more prominent than the influence of the residence. At the same time it is necessary to accentuate the possible interactional effect of these macrosocial phenomena, which was not statistically confirmed but, as mentioned before, is also not possible to exclude. The results confirm that when defining certain constructs such as, for example, social and Machiavellian intelligence, it is inevitable to account for the macrosocial characteristics with a significant status of the cultural influence. The presented results indicate the inevitability to consider not only the direct influence of the macrosocial environment (country), but also its transformation through smaller macrosocial phenomena (residence) and it is not possible to exclude the microsocial environment (family, friends, occupation, school). From the viewpoint of the developing EMESI methodology, which measures social intelligence as a performance characteristic, we consider the presented findings to be one of the further arguments supporting the suitability of this methodology for measuring social intelligence. We are aware of the similarities between the macrosocial environments of the Czech and Slovak Republic, therefore it is necessary to interpret the presented results in the context of the cultural likeness of the two researched samples of respondents.

\section{Acknowledgement}

The report is published with the sponsoring help of the scientific research grant projects VEGA 1/0637/12 and APVV SK-CZ-0173-11. 


\section{References}

Albrecht, K. (2006). Social Intelligence. Leadership Excellence, 23 (11), p. 17-18.

Andrew, J., Cooke, M., \& Muncer, S. (2008). The relationship between empathy and Machiavellianism: An alternative to empathizing-systemizing theory. Personality and Individual Differences, 44, 1203-1211. http://dx.doi.org/10.1016/j.paid.2007.11.014

Bar-On, R. (2006). The Bar-On Model of Emotional-Social Intelligence (ESI). Psicothema, 18, 13-25.

Birknerová, Z., \& Lelková, A. (2012). The Analysis of the Social and Machiavellian intelligence of the managers and head officers in work environment. In Management (p. 257-261). Prešov, Slovakia: FM PU v Prešove.

Calvin, W. (2000). Ako mysli mozog. Vývin inteligencie v minulosti a dnes [How the brain thinks. Development of intelligence in the past and today]. Bratislava, Slovakia: Kalligram.

Christie, R., Geist, F. L. (1970). Studies in Machiavellianism. (1st edition). New York, London: Academic Press.

Frankovský, M. (2010). Behaviorálno-situačný koncept sociálnej inteligencie [Behavioural-situational concept of social intelligence]. In Kognitivny portrét človeka (p. 143 -161). Bratislava, Slovakia: Slovak Academic Press. Retrieved March 10, 2013, from http://www.psychologia.sav.sk/upload/kogpor.pdf

Frankovský, M., \& Birknerová, Z. (2011). Situačný koncept skúmania sociálnej inteligencie revidovaná forma metodiky RIPS(r) [Situational concept of social intelligence research - revised form of RIPS(r) methodology]. In Konference psychologie práce a organizace 2011 [Conference of psychology of labour and organization 2011 ]. Brno, Czech Republic: Ekonomicko-správní fakulta Masarykova Univerzita.

Frankovský, M., \& Birknerová, Z. (2012). Etický rozmer sociálnej inteligencie ako výkonovej charakteristiky [Ethical dimension of social intelligence as a performance measure]. In Psychologica XLI, 163-174. Bratislava, Slovakia: Stimul.

Frankovský, M., Birknerová, Z., Janovská, A., \& Zibrínová, L. (2012). Vybrané kapitoly sociálnej psychológie pre manažérov [Selected chapters of social psychology for managers]. Prešov: Prešovská univerzita v Prešove.

Gardner, H. (1993). Multiple Intelligences: The Theory in Practice. New York, NY: Basic Books.

Goleman, D. (2006). Emotional Intelligence. New York, NY: Bantam Books.

Grams, W. C., Rogers, R. W. (1989). Power and Personality: Effects of Machiavellianism, Need for Approval and Motivation on Use of Influence Tactics. Journal of General Psychology, 117 (1), 71-82. http://dx.doi.org/10.1080/00221309.1990.9917774

Hunter, J. E., Boster, F. J., \& Gerbing, D. W. (1982). Machiavellian Beliefs and Personality: Construct Invalidity of the Machiavellianism Dimension. Journal of Personality and Social Psychology, 43 (6), 1293-1305. http://dx.doi.org/10.1037/0022-3514.43.6.1293 
Kaukiainen, A., Bjőrkqvist, K., Lagerspetz, K., Österman, K., Salmivalli, C., Rothberg, S., \& Ahlborn, A. (1999). The Relationships between Social Intelligence, Empathy, and Three Types of Aggression. Aggressive Behavior, 25, 81-89. doi:10.1002/(SICI)1098-2337(1999)25:2<81::AID-AB1>3.0.CO;2-M

Silvera, D.H., Martinussen, M., \& Dahl, T. (2001). The Thomso Social Intelligence Scale, a self-report measure of Social Intelligence. Scandinavian Journal of Psychology, 42, 313-319.

http://dx.doi.org/10.1111/1467-9450.00242, PMid:11547906

Sternberg, R. J., \& Detterman, D. K. (Eds.). (1986). What is Intelligence? Contemporary viewpoint on its nature and definition. Hillsdale, MI, USA: Ablex.

Vernon P. A., Vilani, V. C., Vickers, L. C., \& Harris, J. A. (2008). A behavioral genetic investigation of the Dark Triad and the Big 5. Personality and Individual Differences, 44, 445-452.

http://dx.doi.org/10.1016/j.paid.2007.09.007 